\title{
Female Labor Force Participation: The Origin of Black and White Differences, 1870 and 1880
}

\section{Citation}

Goldin, Claudia. 1977. Female labor force participation: The origin of black and white differences, 1870 and 1880. Journal of Economic History 37(1): 87-108.

\section{Published Version}

http://www.jstor.org/stable/2119448

\section{Permanent link}

http://nrs.harvard.edu/urn-3:HUL.InstRepos:2643657

\section{Terms of Use}

This article was downloaded from Harvard University's DASH repository, and is made available under the terms and conditions applicable to Other Posted Material, as set forth at http:// nrs.harvard.edu/urn-3:HUL.InstRepos:dash.current.terms-of-use\#LAA

\section{Share Your Story}

The Harvard community has made this article openly available.

Please share how this access benefits you. Submit a story.

Accessibility 


\section{Female Labor Force Participation: The Origin of Black and White Differences, 1870 and 1880}

$\mathbf{T}$ HE participation rate of women in the American labor force increased dramatically over the period 1890 to 1970 , and the jump from 18.9 percent to 42.6 percent indicated to one observer "a genuine revolution, not only in the lives of women, but in the American economy and the American family as well."1 Aggregate figures such as these, however, disguise important underlying changes within various racial and marital groups. (See Table 1.) Although the extensive participation of white women is a recent phenomenon, the same is not true of their black counterparts. The labor force participation for white women more than doubled between 1890 and 1960 , increasing from 16.3 percent to 33.7 percent, while that for non-white women remained almost constant (39.7 percent to 41.7 percent). The most impressive labor market gains during this period were achieved by married white women, who increased their participation rate by over ten times. Although married non-white women also entered the labor force over these years, single non-white women exited as they increasingly were able to afford education and to enjoy the leisure of youth. Therefore the revolutionary increase in the participation of women in the labor force mainly involved whites. Black women had been abundantly represented in the labor market as slaves and had remained so as freed persons.

Many of the reasons for the dissimilar historical experiences of married black and white women are evident. Throughout this period black husbands have had lower labor income and higher unemployment than white husbands, and non-labor income for blacks has also been less than that for whites. Black male mortality has been higher

\footnotetext{
Journal of Economic History, Vol. XXXVII, No. 1 (March 1977). Copyright (C) The Economic History Association. All rights reserved.

The author gratefully acknowledges the help of her colleagues Roger Gordon and Harvey Rosen. Stanley Engerman, Joseph Reid, Hugh Rockoff, Richard Sutch and Harold Woodman commented on an earlier version. Peter Greenhalgh and Hope Reisman laboriously copied and coded information from the census manuscripts, Linda Johnson provided expert research assistance, and Brian Carney helped with the programming. National Science Foundation grant No. SOC75-13630 supported this work by providing funds for research and computation.

1 Robert W. Smuts, Women and Work in America (New York: Columbia University Press, 1959), p. 1.
} 
TABLE 1

FEMALE LABOR FORCE PARTICIPATION RATES BY MARITAL STATUS, RACE, AND NATIVITY, 1890 TO 1970

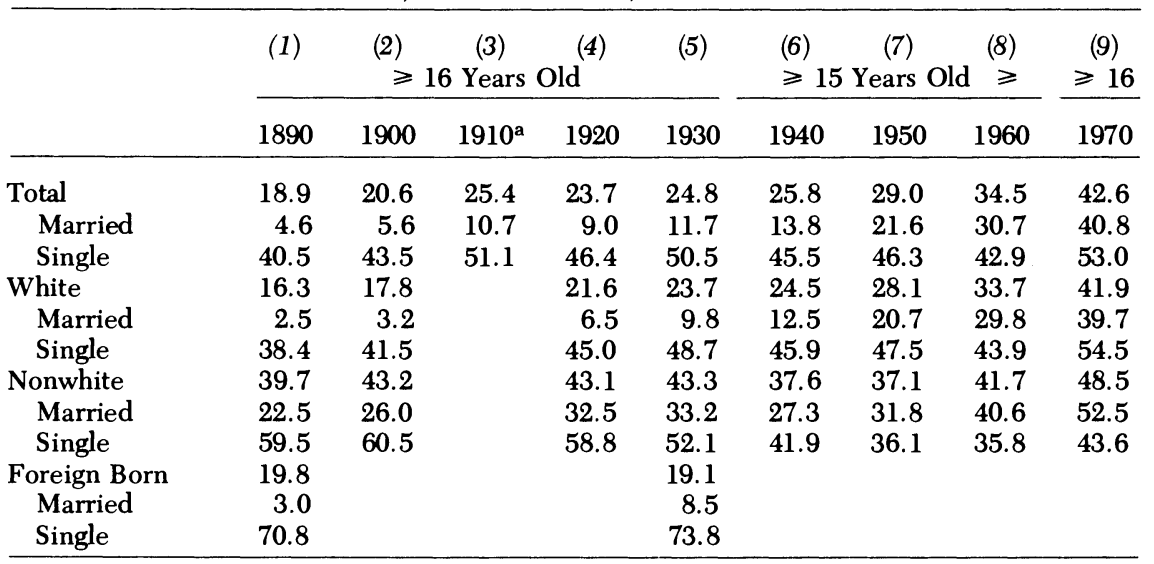

a The 1910 labor force figures are too high relative to those for other years because the census reported certain women employed in agriculture as in the labor force rather than at home. Notes:

Definition of Labor Force: The precise definition of the labor force changed over the period 1890 to 1970. Gertrude Bancroft discusses some of these problems in Appendix C, "Some Problems of Concepts and Measurement," in The American Labor Force: Its Growth and Changing Composition (N.Y.: John Wiley and Sons, 1958).

The largest bias entering this table probably relates to the time period during which the respondent could be at work and still be considered in the labor force. The 1890 to 1930 data will overcount the labor force, in relation to the 1940 to 1970 data, to the extent that people enter and leave the labor force during the year. The former figures will include anyone in the labor force during the year preceding the census, whereas the latter will include those in the labor force during the week preceding the census. However, a mitigating influence is that the 1890 to 1930 figures will not include an unemployed person in the labor force unless that person specifically listed an occupation.

Marital Status: Definition of married in columns (1), (2), (3), (4), and (5) is married, spouse present or absent. That for (6), (7), (8), and (9) is married, spouse present. Definition of single in columns (1), (2), (3), and (5) is single and unknown. That for (4) is single, widowed, divorced, and unknown, and that for (6), (7), (8), and (9) is just single.

Race: White refers to all white, including foreign born, except for (5) where it excludes foreign born. Nonwhite includes Chinese, Japanese, and "civilized Indians" for (1), (6), (7), (8), and (9).

Sources: (1) Eleventh Census of the U.S.: 1890, Parts I and II (Washington: G.P.O., 1897).

(2) Twelfth Census of the U.S.: 1900, Supplementary Analysis and Derivative Tables (Washington: G.P.O., 1906).

(2), (3), (5) Fifteenth Census of the U.S.: 1930, Occupational Statistics, Abstract Summary for the U.S. (Washington: G.P.O., 1932).

(4) Fourteenth Census of the U.S.: 1920, Vol. IV, Occupations (Washington: G.P.O., 1933).

(5) Fifteenth Census of the U.S.: 1930, Population, Vol. V, General Report on Occupations (Washington: G.P.O., 1933).

(6), (7) Special Reports: Employment and Personal Characteristics, U.S. Census of Population: 1950 (Washington: G.P.O., 1963).

(8) Subject Reports: Employment Status and Work Experience, U.S. Census of Population: 1960 (Washington: G.P.O., 1963).

(9) U.S. Dept. of Labor, Bureau of Labor Statistics, Special Labor Force Report No. 129: Employment and Unemployment in 1970 (Washington: G.P.O., 1971). 
than that for whites, and, for other reasons as well, the female-headed family has been more prevalent among blacks.

Much has been learned about the determinants of female labor force participation from research using contemporary (post-1940) data. The presence of preschool children, a woman's education and training, the level of non-labor income, and the husband's unemployment experience have emerged as primary factors. Most importantly, almost all studies have found striking differences between the responses of black and white women to the same environmental and family variables. Black women participate more than whites even when sharing the same characteristics. Differences in family life cycles, discrimination in the housing and labor markets, and measurement problems in valuing part-time labor are among the suggested explanations for this intriguing finding. ${ }^{2}$ Data constraints have unfortunately prevented a thorough study of the historical antecedents to these contemporary racial differences. ${ }^{3}$ Without extensive research in primary sources, we can record women's labor history only from 1890 to the present and can analyze it extensively only for the period beginning in 1940.4

2 William G. Bowen and T. Aldrich Finegan, The Economics of Labor Force Participation (Princeton: Princeton University Press, 1969) is a very comprehensive study which includes an examination of black and white female labor. Bowen and Finegan emphasize differences in marital stability and the problem of part-time service labor in explaining why black women work more than whites even after accounting for age, schooling, other family income, children, and the employment status of the husband. Glen G. Cain, Married Women in the Labor Force: An Economic Analysis (Chicago: University of Chicago Press, 1966) finds that black and white women respond differently in their labor force participation to the presence of preschoolers but that this might be explained by both the greater availability of other family members and different living situations. James A. Sweet, Women in the Labor Force (N.Y.: Seminar Press, 1973) suggests discrimination in both the housing and male job markets as well as differences in family stability as explanations for the diverse labor force experiences of black and white women in his sample. Duran Bell, "Why Participation Rates of Black and White Wives Differ," Journal of Human Resources, 9 (Fall 1974), 465-79, uses more recent data than Bowen and Finegan and gets somewhat different results. Bell still finds that "if black wives had white characteristics, they would work more, not less" than whites (p. 478), but attributes some of the difference to discrimination in the "high-status employment" of white women. Robert E. Hall, "Wages, Income, and Hours of Work in the U.S. Labor Force," Chapter 3 in G. Cain and H. Watts, eds., Income Maintenance and Labor Supply (Chicago: Rand McNally, 1973) summarizes many of the theoretical problems in estimating labor supply functions, particularly that of determining wages for persons who are out of the labor force. Hall also finds that black women respond differently than whites to family, economic, and environmental factors. There are many other excellent articles on labor supply in general and the participation of black and white women-by Boskin, Kosters, Ashenfelter, Mincer and HI. Rosen-but the above list includes those that are most germane to this work.

3 Studies which have attempted to explain the change in female labor force participation through time include Clarence D. Long, The Labor Force Under Changing Income and Employment (Princeton: Princeton University Press for the National Bureau of Economic Research, 1958), and John Durand, The Labor Force in the U.S., 1890 to 1960 (N.Y.: Social Science Research Council, 1948).

${ }_{4}$ There are several recent papers dealing with female labor force participation and family 
In the present essay I attempt to push back these frontiers; my hope is that research on the labor force experience of black women directly following their emancipation will reveal both slavery's effect on racial differences at that time and its impact through time. It is possible that the differences in socialization between antebellum southern black and white women are reflected in their latenineteenth-century labor experiences. The results of these differing socialization processes may have been dissipated through time as succeeding generations of black and white women became more removed from the experiences of their ancestors. Social factors serving to stigmatize work can, however, be resistant to change and could have lingered for many years. ${ }^{5}$ Furthermore, higher participation rates for black women could have influenced both the structure of the black family and migration patterns, thereby reinforcing the initial labor force differences. Although the black family during the twentieth century may have been changed by the urban setting, the black response to urbanization itself may have been conditioned by the slave experience-more precisely by the greater willingness of black

structure in the late nineteenth century, almost all relying heavily on the manuscripts of the Federal Population Census. Elizabeth Pleck, "A Mother's Wages: A Comparison of Income Earning Among Urban Black and Italian Wives, 1896-1911," in Milton Cantor, History of American Working Women (forthcoming) examines why the labor force participation of black and Italian wives differed and suggests many variables, but employs no rigorous tests. Pleck finds an unexplained differential in Italian and black labor force participation and concludes that "cultural norms, economic pressures, and demographic conditions all played a part in determining the choice between work and family for Italian and black wives in American cities. For black women cultural attitudes favored responding to the family's economic need and the offer of higher wage rates, while for Italian wives cultural values took precedence over economic need except under circumstances of high wage rates for female labor." Herbert Gutman, "Persistent Myths About the American Negro Family," Journal of Interdisciplinary History, 6 (Autumn 1975), 181-210, concludes that "slavery and quasi-freedom imposed countless burdens upon American blacks, but the high proportion of two-parent households found among them between 1855 and 1880 tells how little is yet known about the slave family structure, its relationship to the dominant white family structure, and the ways in which freedmen and freedwomen adapted, transformed, retained, or rejected older forms of family life." Frank Furstenberg et al., "The Origins of the Female-Headed Black Family: The Destructive Impact of the Urban Experience," Journal of Interdisciplinary History, 6 (Autumn 1975), 211-34, use data from Philadelphia to evaluate whether "slavery resulted in a permanent deterioration of the black family structure" and whether "family structure accounts for economic disadvantage." John Blassingame, "Before the Ghetto: The Making of the Black Community in Savannah, Georgia, 1865-1880," Journal of Social History, 6 (Summer 1973) gives a general social history of blacks and whites in Reconstruction Savannah. His Black New Orleans 1860-1880 (Chicago: University of Chicago Press, 1973), Chapter 4 explores some data on female-headed families and female labor force participation. Michael R. Haines, "Industrial Work and the Family Cycle, 18891890," (mimeo, April 1976) analyzes the labor force participation of the wives and children of industrial workers using the records of the commissioner of labor.

5 Valerie Kincade Oppenheimer, The Female Labor Force in the U.S.: Demographic and Economic Factors Governing Its Growth and Changing Composition, Population Monograph Series, No. 5 (University of California, Berkeley, 1969) discusses the social stigmatization of women's work in the twentieth century. 
women to work for pay. These are bold conjectures, but they point to the importance of studying the post-emancipation black and white woman. In the present essay I examine the labor record of black and white women in 1870 and 1880 both to extend our historical knowledge of this subject and to develop explanations for the long-run differences between these two groups.

THE SAMPLE

\section{General description}

In order to compute the labor force participation of women in 1870 and 1880 the manuscripts of the United States Population Census have been sampled and to enable an analysis of these data to be made, economic and demographic variables have been coded. Although the compilers of the 1870 and 1880 Federal Population Censuses collected data on occupation and family structure by race and by sex, they did not analyze this information. Fortunately the original data are preserved in the census manuscript collection of the National Archives, and this paper is based on research using these documents. Only cities have been sampled for this study because such data allow a richer analysis than those for rural areas. ${ }^{6}$ Families or households from seven southern cities-Atlanta, Charleston, Richmond, Mobile, New Orleans, Norfolk, and Savannah-were randomly selected. ${ }^{7}$ Information on sex, age, race, marital status (for 1880), health, literacy, occupation, months unemployed (for 1880), wealth (for 1870), nativity, parents' nativity, and the presence of boarders and servants was coded for each selected individual. In total, 5,130 persons were sampled in 1870 and 5,314 in 1880, with blacks comprising 45 percent

\footnotetext{
${ }^{6}$ It would be very difficult to explain the divergent labor market experiences of black and white women in agriculture whose husbands all listed the identical occupation of "farmer." A future study will analyze similar data from rural counties to enable broader conclusions to be drawn and correct for possible biases in this regionally sampled data set.

7 One in fifty pages from the census manuscripts were sampled for all cities except New Orleans, for which one in two hundred were used. All persons, though, have been weighted equally in the analysis. This weighting procedure was used because New Orleans was a disproportionately large city, accounting for 20 percent of the total southern urban population (excluding Kentucky, Missouri, and Maryland) in 1880. Weighting by this factor reduced to 19 percent the percentage of the population accounted for by New Orleans in 1880. Complete households were taken even if they ran over to a succeeding page. This eliminated the bias toward small households inherent in a strict page sampling procedure.

Because information on sex and age was not compiled for cities in the Federal Population Censuses for 1870 and 1880 one cannot determine the biases in these sampled data. I plan to expand this sample and also use those collected by others to ascertain this important information. The more expanded data set will sample more heavily from the non-seaboard urban South.
} 
in 1870 and 41 percent in 1880 . Information on 792 families with both spouses present in 1870 and 813 in 1880 is contained in this sample.

There were, in 1860 , nearly four million slaves in the South and over one-quarter million free blacks. Barely 5 percent of all slaves resided in cities and towns of over 2,500 persons, although about one-third of the free blacks had urban residences. ${ }^{8}$ By 18708.8 percent of all southern blacks lived in cities and most southern cities had become almost one-half black. Blacks had migrated within the South during and directly following the Civil War-many following Union troops for protection and rations; some reuniting with friends and family; and others using their new freedom to escape the rigor of the farm, at least for a while. Some southern cities grew enormously during the period from 1860 to 1870 , and almost every large city increased its proportion of black persons. (See Table 2.) Atlanta, for example, doubled in population over these ten years mainly because its black populace quintupled. The migration of freedmen at the close of the war did not continue long beyond 1870, and the growth of the urban black population moderated considerably during the next ten years. Although blacks migrated within the South, barely a trickle entered the North before 1900 and over 90 percent of all blacks in both 1870 and 1880 resided in the South.

The migration of blacks from the farm to the cities was probably selective. Those who had the desire to work for wages left the countryside and entered towns. Women, especially those who were single, divorced, and widowed, went to the cities to seek employment because they were effectively prohibited from renting farm land. This movement of labor indicates that some information in this sample is particular to the cities. Unmarried females are, for example, overrepresented, and thus one cannot make simplistic comparisons of family structure between the city and the countryside. This is one problem inherent in any regionally sampled data set.

The variables suggested by contemporary labor force studies are used in this paper to analyze the participation of married black and white women during 1870 and 1880. These variables include both economic characteristics, such as family labor income and wealth, and demographic data, such as the wife's age, and the presence of young children. (See Table 3.) These variables are described below for the individuals and families in the sample, and, in the analysis which follows, their interrelationships will become more apparent.

\footnotetext{
${ }^{8}$ See Claudia Goldin, Urban Slavery in the American South (Chicago: University of Chicago Press, 1976), Table 1, p. 12.
} 


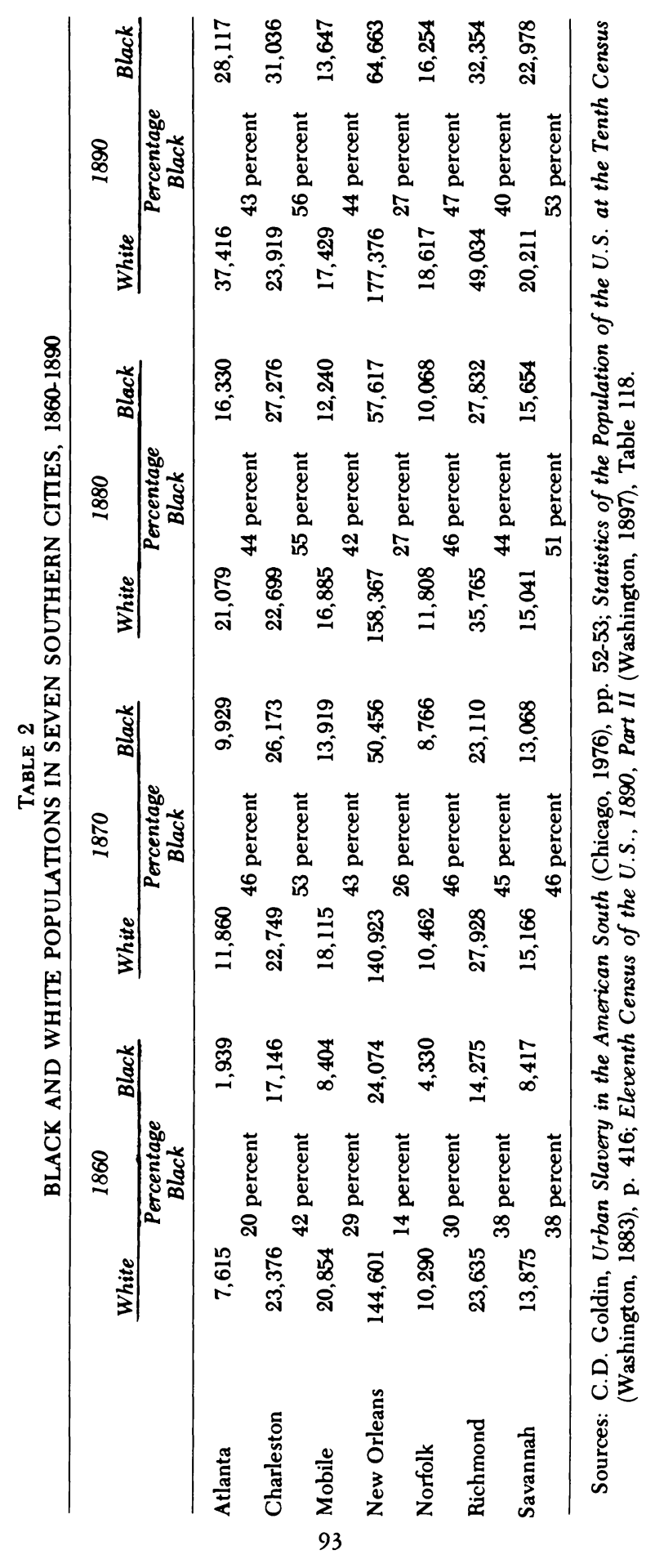




\begin{tabular}{|c|c|c|c|c|}
\hline \multirow{3}{*}{$\frac{\text { Age }}{1870}$} & \multicolumn{4}{|c|}{$\begin{array}{c}\text { TABLE } 3 \\
\text { AGE DISTRIBUTION BY RACE AND SEX, } 1870 \text { AND } 1880 \\
\text { (for seven southern cities) }\end{array}$} \\
\hline & \multicolumn{2}{|c|}{ Black } & \multicolumn{2}{|c|}{ White } \\
\hline & Female & Male & Female & Male \\
\hline $0-4$ & 9.4 percent & 13.2 percent & 12.0 percent & 13.2 percent \\
\hline $5-9$ & 9.5 & 10.7 & 11.0 & 9.9 \\
\hline $10-14$ & 12.4 & 13.0 & 10.8 & 10.8 \\
\hline $15-19$ & 10.2 & 9.5 & 10.6 & 10.4 \\
\hline $20-29$ & 21.4 & 18.2 & 20.7 & 19.1 \\
\hline $30-39$ & 13.7 & 15.0 & 13.8 & 13.8 \\
\hline $40-49$ & 11.2 & 10.5 & 10.9 & 12.0 \\
\hline $50-64$ & 8.2 & 7.1 & 8.0 & 8.9 \\
\hline over 64 & 3.9 & 2.8 & 2.2 & 1.8 \\
\hline No. in sample & 1,292 & 1,030 & 1,476 & 1,332 \\
\hline \multicolumn{5}{|l|}{1880} \\
\hline $0-4$ & 9.8 & 13.2 & 9.9 & 10.8 \\
\hline $5-9$ & 10.2 & 14.0 & 10.8 & 11.4 \\
\hline $10-14$ & 10.2 & 11.9 & 10.1 & 10.4 \\
\hline $15-19$ & 9.3 & 8.5 & 11.3 & 9.1 \\
\hline $20-29$ & 21.9 & $14.6^{\mathrm{a}}$ & 20.6 & 20.4 \\
\hline $30-39$ & 16.0 & 14.4 & 13.8 & 14.0 \\
\hline $40-49$ & 8.9 & 13.2 & 10.5 & 11.8 \\
\hline $50-64$ & 10.0 & 7.9 & 9.8 & 9.4 \\
\hline over 64 & 3.8 & 2.4 & 3.3 & 2.7 \\
\hline No. in sample & 1,226 & 958 & 1,643 & 1,487 \\
\hline
\end{tabular}

${ }^{a}$ Even though age distributions by sex were not substantially different for blacks and whites in 1870 , they had become considerably altered by 1880 . Black males between the ages of 20 to 29 comprised only 14.6 percent of their group, whereas 20.4 percent of white males were between these ages. This short-fall in the number of black males was so high that black women in this age category outnumbered black men by almost two to one. Although it is possible that this imbalance was caused by the selective migration of single black women, it is also possible that there was an undercount of single black men in that age category.

Source: Manuscripts of the U.S. Population Census. See text for a complete description of the sampling procedure.

\section{Economic variables}

The most striking differences between blacks and whites in these data involve economic variables. Black women participated in the labor force on average three times more than did white women, and married black women averaged almost six times the rate of married white females. (See Table 4.) Single black women across all age categories labored more in 1880 than in 1870 , and by 1880 their participation rate was 73.3 percent, an increase in that decade of ten percentage points. The rate for single white women was about the same for the two years. Both married black women and married white women participated more in 1880 than in 1870 (the figure for the 


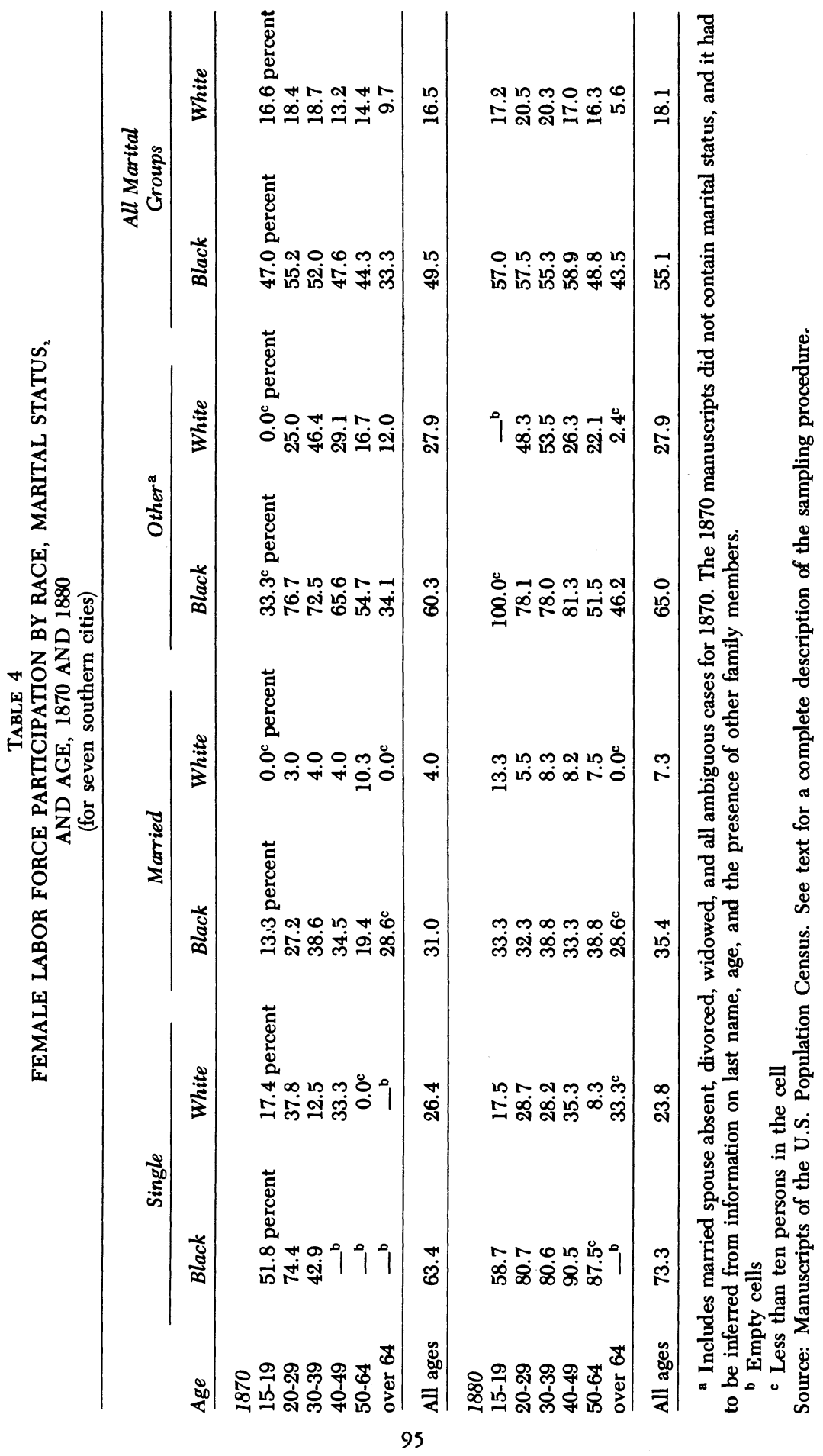


latter group rose from 4.0 percent to 7.3 percent). Widowed and divorced black women also increased their rate of participation, although white women in this group did not.

The impressive change in the participation by single black women in these seven cities between 1870 and 1880 can be explained conjecturally by two very different theories. The increase might have reflected a migration to the cities of those desiring work. These women might have become live-in domestics for urban white families, although the occupational data in this sample do not substantiate this thesis. ${ }^{9} \mathrm{~A}$ second possibility is that this increase in participation indicates a change in the work habits of those already in the city. Black women. may have withdrawn their labor directly following emancipation but then reentered the labor force after a short period of adjustment. ${ }^{10}$

Black women as a group labored more intensively than whites but occupied lower paying positions. (See Table 5.) They were abundantly represented in the ranks of the unskilled. About 10 to 15 percent of those over nine years old were laundresses-women who generally worked at home, taking in clothes and working by the piece-and between 19 to 23 percent were servants, 70 to 75 percent of whom lived in the home of their employer. Cooks, nurses, and seamstresses were also among the more common occupations. Few black women were proprietors and clerical workers, and variety in employment for black women was limited, in part due to the lack of a large manufacturing sector in the urban South.

Black men were also more prevalent in the labor force in comparison with whites. Only 4.8 percent of all black males over 14 years old stated that they were not working, whereas 8.5 percent of white males declared no occupation. Black males were, however, subject to more unemployment, on average 3 weeks per year as compared to 1.6 weeks for whites who listed an occupation. Black men also had lower paying occupations than whites. They were abundantly represented in the unskilled category but few appear in professional, clerical, and proprietary employments. They were, though, about equally represented in the skilled trades, which included carpentry, masonry,

9 Data on servants show a decrease from 1870 to 1880 in the percentage of black women who were live-in domestics.

10 Roger Ransom and Richard Sutch, One Kind of Freedom, The Economic Consequences of Emancipation (New York: Cambridge University Press, forthcoming) discuss the withdrawal of black female and child labor directly after emancipation and claim that the period of readjustment was over by 1868 . 
TABLE 5

FEMALE OCCUPATIONAL DISTRIBUTION

(percentage over nine years old in seven southern cities)

\begin{tabular}{|c|c|c|c|c|}
\hline & \multicolumn{2}{|l|}{ Black } & \multicolumn{2}{|l|}{ White } \\
\hline & 1870 & 1880 & 1870 & 1880 \\
\hline No occupation ${ }^{a}$ & 18.8 percent & 16.2 percent & 26.0 percent & 26.4 percent \\
\hline At home & 36.4 & 33.8 & 59.6 & 58.1 \\
\hline Servant & 23.3 & 18.8 & 5.7 & 3.5 \\
\hline Laundress & 10.5 & 14.7 & $0.4^{t}$ & 0.6 \\
\hline Cook & 2.4 & 5.5 & $0.2^{t}$ & 0.5 \\
\hline Unskilled $^{\mathbf{b}}$ & 3.4 & 3.6 & $0.4^{f}$ & 0.6 \\
\hline Prostitute & $0.1^{1}$ & -e & $0.1^{t}$ & 0.7 \\
\hline Nurse & 1.8 & 2.1 & $0.1^{1}$ & 0.2 \\
\hline Seamstress, milliner & 3.1 & 3.7 & 5.4 & 6.1 \\
\hline Semiskilled ${ }^{c}$ & $0.1^{1}$ & - e & -e & $0.2^{t}$ \\
\hline Skilled $^{\mathrm{d}}$ & -e $^{e}$ & $0.4^{t}$ & $0.2^{1}$ & -e \\
\hline Clerical, teacher & $0.1^{1}$ & 0.7 & $0.4^{1}$ & 2.1 \\
\hline Proprietor, boardinghouse keeper & - e & $0.4^{t}$ & 1.6 & 1.1 \\
\hline
\end{tabular}

a "No occupation" and "at home" differ only slightly in interpretation. "At home" was listed as the occupation for persons the census taker believed were old enough to have an occupation. "No occupation" was listed for those who were very young or very old, and a blank was given for those who were young.

b Includes laborers, packers, porters, janitors, milkwomen, agricultural laborers, peddlers, and so on.

c Includes manufacturing workers giving a precise occupation (not "laborer"), and hairdressers.

d Includes apprentices, painters, and bookbinders.

e Empty cell

1 Less than five persons in a cell

Source: Manuscripts of the U.S. Population Census. See text for a complete description of the sampling procedure.

cabinet making, painting, and so on. This "legacy of slavery" was especially pronounced in Charleston, where most artisans, even by 1890, were black. ${ }^{11}$ On balance, however, slavery's legacy was to weight occupations toward the lower end of the wage and class spectrum; on net, black men and women swelled the ranks of the lesser skilled.

Family labor income is determined by two variables - the potential wage of family members and their labor force participation. ${ }^{12}$ Blacks had much higher rates of participation than whites but lower occupational skills, and thus black family labor incomes were considerably less than those for whites. Blacks had 57.8 percent of white family

11 Claudia Goldin, Urban Slavery in the American South discusses the extensive use of slave artisans in antebellum cities. The Epilogue of that book summarizes what became of these skills after 1865.

12 A family is defined here as consisting of at least a husband and a wife. The term "labor income" is used because income from property is, for the most part, excluded. 


\begin{tabular}{|c|c|c|c|}
\hline & \multicolumn{3}{|c|}{$\begin{array}{c}\text { TABLE } 6 \\
\text { MEAN FAMILY LABOR INCOME BY RACE, } 1870 \text { and } 1880 \\
\text { (for seven southern cities) }\end{array}$} \\
\hline & Total & Per Capita & $\begin{array}{c}\text { Mean } \\
\text { Family Size }\end{array}$ \\
\hline \multicolumn{4}{|l|}{ Black } \\
\hline 1870 & 558.4 & 178.6 & 3.58 \\
\hline 1880 & $547.8(584)^{\mathrm{a}}$ & $172.0(184)$ & 3.78 \\
\hline \multicolumn{4}{|l|}{ White } \\
\hline 1870 & 966.1 & 259.1 & 4.17 \\
\hline 1880 & $915.4(936)$ & $247.2(254)$ & 4.31 \\
\hline
\end{tabular}

a Figures in parentheses are labor income assuming months unemployed equalled zero. This enables comparisons with 1870 for which no unemployment data were available.

Note: Family labor income was computed by assigning monthly wages rates to occupations, multiplying by 12 minus months unemployed, and adding together the husband's, wife's, and children's components. The wage rates used are based on contemporary sources and vary by sex and age, with children under 15 years given half the adult wage for their occupation. These data are available from the author and are in an Appendix: Wages for Various Occupations, 1870 and 1880. The absolute value of family income is not necessarily correct. Families are defined here as married persons with both husband and wife present.

Source: Manuscripts of the U.S. Population Census. See text for a complete description of the sampling procedure.

labor income in 1870 and 62.4 percent in 1880. (See Table 6.) On a per capita basis black families fared slightly better, and each family member received 68.9 percent of a white's per capita labor income in 1870 and 74.4 percent in 1880 . The mean family wealth of whites in this sample was about $\$ 1,500$, the median $\$ 390$ and the distribution was right skewed with 45.5 percent of the families reporting no wealth in excess of $\$ 100$. Black families, not surprisingly, had very little wealth-far less than their current labor incomes might indicate-with over 85 percent reporting none over $\$ 100$. The sample mean was $\$ 125$ and the median only $\$ 40$, even though fully 6 percent had managed to accumulate over $\$ 500$. Later censuses do not contain information on wealth, and although the extent of asset accumulation by blacks from 1870 to 1880 could not have been substantial, the percentage of black male proprietors in the sample rose from 6.6 percent to 10.1 percent of the total.

Black and white family income varied differentially over the husband's age and the components of family income also differed by race. The white husband's income tended to peak around the age of 40 to 49 years, and although the average black husband reached a maximum income at approximately the same age, the peak was considerably less pronounced. ${ }^{13}$ This pattern could reflect an occupa-

13 The age-income profile for black males in 1870 is even flatter. 
tional structure for blacks that changed less with their age, but it probably indicates that younger cohorts were entering better occupations. Black women contributed to family income over the full lifetime of their husbands, supplementing their lessened earning power in later years. Black children within each age group participated in the labor force more than did white youngsters, but somewhat paradoxically, black children on average worked less than whites-13.4 percent of all black children had occupations in 1880 compared with 17.5 percent for white children. This difference results from the earlier withdrawal of children over twenty years old from the urban black family. The age structure of children living with families therefore accounts for the surprising finding that although black children had high participation rates by age they contributed little to family income.

\section{Demographic variables}

Although there is an extensive literature that stresses the demographic contrasts between the black and white family, these data do not reveal many differences. ${ }^{14}$ Black and white women were equally represented across the various marital categories. (See Table 7.) The percentage of black families with children which were headed by a female was identical to that for whites in 1880. Approximately 30 percent of all two-parent and female-parent families with at least one child were headed by a female, for both blacks and whites. ${ }^{15}$ These data, of course, cannot alone refute the tale of black family instability, because they do not contain information on past marriages. But they

${ }^{14}$ E. Franklin Frazier, The Negro Family in the U.S., rev. ed. (Chicago: University of Chicago Press, 1969), popularized the notion that the twentieth-century matrifocal black urban family was a product of slavery. Gutman, "Persistent Myths About the American Negro Family," and Furstenberg et al., "The Origins of the Female-Headed Black Family," are two excellent reexaminations and challenges to Frazier's work.

15 A female-headed family is defined as a woman with at least one child, and a two-parent family is one with both husband and wife and at least one child. These distinctions get around the problem of using the census marshal's determination of "head of household," and use, instead, an operational definition. Note that families with only a father or a male head with a child have been excluded. It is difficult to contrast these results with those of Gutman and Furstenberg. See Gutman, "Persistent Myths . . .," and Furstenberg et al., "The Origins of the Female-Headed Black Family." Both the Gutman and Furstenberg data are grouped by households and not by nuclear families. A widowed mother living with her parents, for example, would not be counted in these data sets. Furthermore Gutman includes as households individuals who live alone and childless couples. Therefore a high proportion of single persons without children or childless couples could distort his findings.

My results appear to indicate a higher percentage of female-headed families in the cities than in rural areas for both blacks and whites. This is not a surprising finding considering the selective migration of such individuals from the countryside to the city in search of jobs and relatives. 
TABLE 7

MARITAL STATUS BY SEX AND RACE, 1870 AND 1880

(for seven southern cities)

\begin{tabular}{|c|c|c|c|c|c|c|}
\hline & \multicolumn{2}{|l|}{ Single } & \multicolumn{2}{|l|}{ Married } & \multicolumn{2}{|l|}{ Other ${ }^{\mathrm{a}}$} \\
\hline & White & Black & White & Black & White & Black \\
\hline \multicolumn{7}{|l|}{1870} \\
\hline Male & 57.9 & 57.9 & 33.3 & 34.1 & 8.9 & 8.1 \\
\hline $\begin{array}{l}\text { No. of } \\
\text { obs. }{ }^{b}\end{array}$ & $\begin{array}{c}787 \\
(771)\end{array}$ & $\begin{array}{c}658 \\
(596)\end{array}$ & $\begin{array}{c}446 \\
(443)\end{array}$ & $\begin{array}{c}352 \\
(351)\end{array}$ & $\begin{array}{c}243 \\
(118)\end{array}$ & $\begin{array}{l}282 \\
(83)\end{array}$ \\
\hline \multicolumn{7}{|l|}{1880} \\
\hline Female & 55.8 & 52.4 & 28.1 & 29.5 & 16.1 & 18.0 \\
\hline Male. & 62.9 & 58.6 & 31.4 & 37.4 & 5.6 & 4.1 \\
\hline $\begin{array}{l}\text { No. of } \\
\text { obs. }\end{array}$ & $\begin{array}{c}917 \\
(936)\end{array}$ & 643 & 461 & 362 & 265 & 221 \\
\hline
\end{tabular}

a Includes widowed, divorced, married spouse absent, and any ambiguous cases for 1870 . The population census did not report family relationships for 1870 and marital status had to be inferred from other information, such as the similar age of a male and female with identical last names. Marital status was coded as unknown when it was ambiguous, and the unknown category has been grouped with "other" in this table. Black women outnumbered white women in this group, and this reflects part of the transition from slavery to freedom. Directly following the Civil War black women and men reunited and those who had been recently married as freedmen were in the process of changing their last names. By 1880 this process appears to have been completed because all marital groups were equally represented by race.

b Number of observations. Figures for males are in parentheses.

Source: Manuscripts of the U.S. Population Census. See text for a complete description of the sampling procedure.

do reveal that urban black children in 1880 experienced the presence of a two-parent family in the same proportion as did white children.

Black urban families in this sample were smaller on average than were white families - there were 1.78 black children per two-parent family in 1880 but 2.31 white. ${ }^{16}$ Black fertility, however-measured by children 0 to 4 years old per thousand women 15 to 44 - was not correspondingly lower. Black fertility exceeded that for whites in this sample for 1870 (258 versus 213) and equalled it for 1880 (262 versus 261). ${ }^{17}$ Although black fertility was somewhat higher, it is compatible with smaller family size because black infant mortality was probably greater and black children exited from their nuclear families at an earlier age than white children. The percentage of all children living at home who were over 19 years old was 17.1 percent for whites but

16 Note that this is the mean number of children per nuclear family, not per household. Families here can include childless couples but are defined as having both husband and wife present.

${ }_{17}$ This decline in black fertility continued, and by 1910 the white figure considerably exceeded that for blacks in the urban South. See Stanley Engerman, "Changes in Black Fertility, 1880-1940," (mimeo, July 1974) for a description and some analysis of the decline in black fertility after 1880 . 
only 8.2 percent for blacks. There is no obvious explanation for this difference, but it seems likely that older white children were still at home because they could be more dependent on their parents' income and wealth and had higher rates of school attendance than did their black counterparts.

\section{AN ANALYSIS OF MARRIED WOMEN IN THE LABOR FORCE:}

RACIAL DIFFERENCES

Married black and white women have had different labor force participation rates throughout American history. The difference during the period up to 1865 can be explained by the institution of slavery, and much after that date can also be attributed to the slave experience. This "legacy of slavery" has been both economic and social, both direct and indirect. Slavery directly affected the labor force participation of newly freed blacks by altering their economic earning power. By lowering the husband's earnings, slavery directly induced black wives to enter the labor force, and lower parents' income meant that more black children worked. The almost total lack of wealth among black families implied that unemployment of the primary worker, usually the husband, was a harsh reality which doubtless forced other family members into the labor force.

The slave experience also had an indirect or social impact. Black women were conditioned by slavery to laboring-work for pay was less socially stigmatizing to them than it was to white women. As Carter G. Woodson, in his article on the Negro washerwoman, cogently observed: "Many poor whites of that day were not any better off than the Negroes, but they were too proud to work." ${ }^{18}$ A confirmation of this statement is contained in this study's data. Only 14 percent of white women with low family labor income (\$0 to \$299) were in the work force in 1880 , but over 44 percent of low-income married black women were. In 1870 the comparable figures were 5 percent for whites and 37 percent for blacks. Holding wealth constant at zero does not substantially reduce this difference- -40 percent of low-income, zero-wealth blacks and only 7 percent of this category of whites were in the labor force.

There are other variables in addition to family labor income and wealth that can be important determinants of the labor force participation of married women. The presence of young children not in

18 Carter G. Woodson, "The Negro Washerwoman: A Vanishing Figure," Journal of Negro History, 15 (July 1930), 274. 
school, the health of a woman, and her income-earning ability, are a few. By holding these factors constant one can observe differences in labor force participation that can be attributed to race. The direct effects of slavery-those that influence earning power, asset accumulation, and family structure - can in this way be separated from the indirect ones. The conventional method employed for such analysis is that of regression, but simple ordinary least squares techniques are not necessarily acceptable procedures when the dependent variable is dichotomous, and one solution is to employ a probit analysis model. ${ }^{19}$ This model constructs an index, I, which is a linear function of the independent variables. The value of the standard normal cumulative distribution at $I$ is the probability that a female will be in the labor force, given the vector of characteristics used to construct I. The coefficients of the index are estimated to maximize the probability of reproducing the choices made by those in the sample-that is, to maximize the likelihood of the sample.

The results of the probit analysis (using the sample data) are given in Table 8. The dependent variable is the labor force participation of the wife and is dichotomous-either a women is in the labor force or is not-and the observations are for married women, husband present. ${ }^{20}$ The independent variables are all dichotomous except:

Per Capita $\mathrm{Y}=$ per capita family labor income divided by 100 (without the wife's contribution);

LnWealth $=$ the log of family real and personal estate;

Husband Unemployed $=$ the number of months the husband was unemployed during the previous year.

The family labor income variable was computed by assigning wage rates to the various occupations, by accounting for months unemployed (for 1880) and differences among men, women, and children, and by summing the contributions of each family member. ${ }^{21}$ Regres-

19 Two problems arise in the case of a dichotomous dependent variable-that of heteroskedasticity and that of specification. The first is not particularly troublesome for very large samples, but the second is serious because the predicted values from ordinary least squares will not be bounded on the unit interval. This creates difficulties in interpreting the results as conditional probabilities of being in the labor force. For a more complete exposition see Arthur Goldberger, Econometric Theory (N.Y.: John Wiley and Sons, 1971), pp. 248-51 which discusses qualitative and limited dependent variables, and Henri Theil, Principles of Econometrics (N.Y.: John Wiley and Sons, 1971), which has a short section on probit analysis, pp. 630-31.

20 Sixteen families in 1870 and six in 1880 were listed as having no family member in the labor force and no wealth. These were dropped from the sample as being anomalous. They probably contained a working family member who was not in the nuclear family or not living in the same household.

21 An appendix to this paper, Wage Data for Various Occupations in the South, 1870 and 1880, details the construction of these components and the sources used. It can be obtained by request from the author. 
TABLE 8

MARRIED WOMEN IN THE LABOR FORCE, 1870 AND 1880: PROBIT ANALYSIS MODEL

Dichotomous $(0,1)$ Dependent Variable: Female labor force participation for married women, husband present.

\begin{tabular}{|c|c|c|c|}
\hline \multirow[b]{3}{*}{$\begin{array}{l}\text { Independent } \\
\text { Variables } \\
\end{array}$} & \multicolumn{3}{|c|}{ Maximum Likelihood Estimates } \\
\hline & \multirow{2}{*}{$\begin{array}{c}1870 \\
\begin{array}{c}(1) \\
\hat{\beta}\end{array}\end{array}$} & \multicolumn{2}{|c|}{1880} \\
\hline & & $\begin{array}{l}(2) \\
\hat{\boldsymbol{\beta}}\end{array}$ & $\begin{array}{l}(3) \\
\hat{\beta}\end{array}$ \\
\hline Constant & $\begin{array}{c}-0.884 \\
(0.300)^{\mathrm{a}}\end{array}$ & $\begin{array}{c}-1.030 \\
(0.240)\end{array}$ & $\begin{array}{r}-1.176 \\
(0.247)\end{array}$ \\
\hline Race & $\begin{array}{c}0.812 \\
(0.201)\end{array}$ & $\begin{array}{c}0.954 \\
(0.150)\end{array}$ & $\begin{array}{c}0.967 \\
(0.151)\end{array}$ \\
\hline Foreign & $\begin{array}{c}-0.243 \\
(0.248)\end{array}$ & $\begin{array}{c}0.122 \\
(0.207)\end{array}$ & $\begin{array}{c}0.161 \\
(0.207)\end{array}$ \\
\hline Child Ten ${ }^{\mathrm{b}}$ & $\begin{array}{c}-0.482 \\
(0.147)\end{array}$ & $\begin{array}{c}-0.410 \\
(0.131)\end{array}$ & $\begin{array}{r}-0.375 \\
(0.133)\end{array}$ \\
\hline Health & & $\begin{array}{c}-0.452 \\
(0.648)\end{array}$ & $\begin{array}{r}-0.516 \\
(0.677)\end{array}$ \\
\hline $\operatorname{Age}^{c} 25-29$ & $\begin{array}{c}0.150 \\
(0.213)\end{array}$ & $\begin{array}{c}0.282 \\
(0.193)\end{array}$ & $\begin{array}{c}0.284 \\
(0.193)\end{array}$ \\
\hline $30-34$ & $\begin{array}{l}0.427 \\
(0.217)\end{array}$ & $\begin{array}{c}-0.029 \\
(0.209)\end{array}$ & $\begin{array}{c}-0.016 \\
(0.209)\end{array}$ \\
\hline $35-39$ & $\begin{array}{c}0.304 \\
(0.220)\end{array}$ & $\begin{array}{c}0.481 \\
(0.194)\end{array}$ & $\begin{array}{c}0.484 \\
(0.195)\end{array}$ \\
\hline $40-49$ & $\begin{array}{c}0.245 \\
(0.196)\end{array}$ & $\begin{array}{c}0.134 \\
(0.200)\end{array}$ & $\begin{array}{c}0.121 \\
(0.201)\end{array}$ \\
\hline 50 and over & $\begin{array}{c}0.050 \\
(0.255)\end{array}$ & $\begin{array}{c}0.156 \\
(0.210)\end{array}$ & $\begin{array}{c}0.123 \\
(0.211)\end{array}$ \\
\hline Per Capita Y & $\begin{array}{c}-0.201 \\
(0.074)\end{array}$ & $\begin{array}{c}-0.182 \\
(0.059)\end{array}$ & $\begin{array}{r}-0.133^{\mathrm{d}} \\
(0.059)\end{array}$ \\
\hline Board & $\begin{array}{c}-0.306 \\
(0.502)\end{array}$ & $\begin{array}{c}-0.196 \\
(0.199)\end{array}$ & $\begin{array}{c}-0.218 \\
(0.199)\end{array}$ \\
\hline Servant & $\begin{array}{c}-0.563 \\
(0.332)\end{array}$ & $\begin{array}{c}-0.377 \\
(0.264)\end{array}$ & $\begin{array}{r}-0.376 \\
(0.263)\end{array}$ \\
\hline Husband Unemployed & & & $\begin{array}{c}0.070 \\
(0.026)\end{array}$ \\
\hline LnWealth & $\begin{array}{c}-0.053 \\
(0.026)\end{array}$ & & \\
\hline$-2 \times L_{L} R^{e}$ & 148.8 & 131.1 & 134.0 \\
\hline $\begin{array}{l}\text { Percentage Predicted Correctly } \\
\text { Number of Observations }\end{array}$ & $\begin{array}{l}84.1 \\
776\end{array}$ & $\begin{array}{l}81.7 \\
807\end{array}$ & $\begin{array}{l}81.5 \\
807\end{array}$ \\
\hline
\end{tabular}

a Standard errors are in parentheses.

b Child Ten indicates the presence of at least one child ten years and under who is not in school.

c The age group from 15 to 24 years was the omitted dummy variable.

" Family income is constructed for this case as a "full income" concept with months unemployed equal to zero.

e Minus two times the log likelihood ratio, which has the chi-square distribution with 12 degrees of freedom for regressions (1) and (2) and 13 for (3). The null hypothesis is that all coefficients are zero.

sion (3), for 1880, used the husband's months unemployed as a separate explanatory variable and, for that specification, the income 
variable assumed no unemployment. The other, all dichotomous, variables describe the wife and are:

Five age dummies: 15 to 24 years old is the omitted dummy.

Race: 0 = white; 1 = black.

Foreign: $0=$ native born; $1=$ foreign born.

Child Ten: $0=$ no children 10 years old or under except those attending school; $1=$ presence of children 10 years old or under, not in school.

Health: $0=$ no health problem; $1=$ some health problem.

Board: 0 = does not have boarders; $1=$ has boarders.

Servant: $0=$ does not have a servant; $1=$ has a servant.

The wealth variable was available only for 1870 , unemployment only for 1880 , and health status was reported too infrequently in 1870 to be used. ${ }^{22}$

Coefficients are listed for one specification for 1870 and two for $1880 .{ }^{23}$ Almost all coefficients have the expected sign. The presence of preschoolers had a negative impact on female labor force participation; less healthy women tended to stay out of the labor force; wives with richer families, as measured by the per capita labor income and wealth, were less likely to be in the labor force; and a husband's unemployment induced his wife to enter the labor force. Boarders and servants were included as proxies for wealth, and both had a negative impact on the index. The foreign-born dummy was negative for 1870 and positive for 1880 , although there is no readily available explanation for this result. The age dummies for 1870 rose to $30-34$ years and then declined, but they had no clear trend for 1880 .

The magnitudes of the coefficients generated by the probit estimating procedure are not by themselves interesting. One cannot directly determine the percentage change in female labor force participation by increasing, for example, income by one percent; this is true

\footnotetext{
22 There is no obvious reason why health status was underrecorded in 1870 .

${ }^{23}$ Other explanatory variables which were tried include illiteracy and the presence of other non-working family members over 15 years old. The first, measured by the ability both to read and to write, yielded an insignificant coefficient. This indicates, perhaps, that literacy is not a good measure of a women's earning ability for the nineteenth century. The "other family member" variable had the wrong sign, probably due to the method of coding the data. Families having either a wife or a husband with children were coded as separate units even if they were living with another family. Therefore the category "other family members" can only include children and unattached individuals. However, the existence of an aunt living with a family, for example, might indicate that there was, in addition, another complete family in the household. Although the presence of an aunt might enable a wife with a preschooler to work, the presence of other working adults might be an economic deterrent to such behavior.

Specifications which include only blacks appear very similar to those given in Table 8 . Regressions for whites only had similar coefficients on Child Ten and Per Capita Y but had much larger standard errors.
} 
because such an elasticity is conditional on the values for all other independent variables. To compute the probability that a woman with a particular vector of characteristics is in the labor force, an index $(\mathrm{I})$ is constructed as in equation (1), conditional on values for all the included variables.

$$
\hat{\mathrm{I}}=\hat{\beta}_{0}+\hat{\beta}_{1} \mathbf{X}^{\prime}{ }_{1}+\hat{\beta}_{2} \mathbf{X}^{\prime}{ }_{2}+\ldots+\hat{\beta}_{\mathrm{n}} \mathbf{X}^{\prime}{ }_{\mathrm{n}} .
$$

This index is then evaluated using the cumulative standard normal distribution,

$$
\hat{\mathbf{y}}=\mathrm{F}(\hat{\mathbf{I}}) \text {. }
$$

Particular variables can then be changed to observe their effects conditional on values for all the other variables.

Table 9 has been constructed to illustrate this procedure and to

TABLE 9

CONDITIONAL PROBABILITIES OF PARTICIPATING

\begin{tabular}{|c|c|c|c|c|}
\hline & \multicolumn{2}{|c|}{ White } & \multicolumn{2}{|c|}{ Black } \\
\hline & Child Ten ${ }^{a}$ & No Child Ten & Child Ten & No Child Ten \\
\hline \multicolumn{5}{|c|}{ ( } \\
\hline Wealth $=\$ 0$ & & \multicolumn{3}{|c|}{$\begin{array}{l}\text { For a married woman, husband present, who is } 35 \text { to } 39 \\
\text { years old and native born, and has no servants, and no } \\
\text { boarders }\end{array}$} \\
\hline
\end{tabular}
IN THE LABOR FORCE

Per capita family labor income $=$

$\begin{array}{lllll}\$ 218^{\text {b }} & 6.7 \text { percent } & 15.4 \text { percent } & 24.5 \text { percent } & 41.7 \text { percent } \\ \$ 180^{\text {c }} & 7.8 & 17.4 & 27.1 & 44.8 \\ \$ 248^{\text {d }} & 5.9 & 14.1 & 22.7 & 39.4 \\ \text { Wealth }=\$ 500 & & & \\ \text { Per capita family labor income }= & & & \\ \$ 218 & 3.4 & 8.9 & 15.4 & 29.5\end{array}$

1880

For a married woman, husband present, who is 35 to 39 years old, in good health, and native born, and has no servants, and no boarders

Per capita family labor income $=$

\begin{tabular}{lrrrr}
$\$ 205^{\mathrm{b}}$ & 9.2 & 17.9 & 35.2 & 51.2 \\
$\$ 165^{\mathrm{c}}$ & 10.4 & 19.8 & 37.8 & 54.0 \\
$\$ 236^{\mathrm{d}}$ & 8.1 & 16.1 & 33.0 & 48.8 \\
\hline
\end{tabular}

a Child Ten indicates the presence of at least one child ten years and under who is not in school.

b This is the mean per capital family labor income (without the wife's contribution) for both blacks and whites.

c This is the mean for black families.

d This is the mean for white families.

Source: Table 8 . 
analyze the data. The expected labor force participation rate of black and white women between 35 to 39 years old is analyzed by income, wealth, and the presence of young children, assuming all other dummy variables equalled zero. The difference between the black and white probabilities of participation are large, even though several important explanatory variables are held constant. Black and white women with identical family labor income, equal to $\$ 218$, no wealth, and no young children differ in expected labor force participation by 26 percentage points in 1870 and 33 percentage points in 1880 . The presence of a preschooler lowers the probabilities for both black and white women but has a greater percentage impact on white women. The white probability for 1870 is cut by 56 percent and the black by 41 percent. Comparable figures for 1880 are 48 percent and 31 percent. Increasing per capita family labor income reduces the probability of a woman's working. The elasticity around the mean income for 1870 was -0.68 for whites and -0.41 for blacks. Similar results were obtained for $1880 .{ }^{24}$ Increasing wealth to $\$ 500$ reduces the conditional probabilities, and the white response to this change is, again, somewhat larger. The effect of separating the income variable into two components-one a "full time" labor income variable and the other a measure of the husband's unemployment-is revealing. Increasing a husband's unemployment by one month augments the index, equation (1), by 0.07 -equivalent to decreasing family labor income by $\$ 50$. The wife, therefore, was purchasing a substantial insurance policy against her husband's being unemployed because per capita income was, on average, about $\$ 200$.

The labor force participation of married black women for these southern cities was not enormously high by today's standards and certainly not by the norms of the antebellum period. It was very high, however, by the white standard of the day. Numerous relevant variables have been used in this study to account for the difference, but race appears to have had an effect apart from income, wealth, and demographic characteristics. One possible reason for this result is that there may be important omitted variables which are correlated with race. ${ }^{25}$

24 Using the current status measure of employment Cain found, for 1960 data, that the white elasticity was -0.45 and the black -0.13 . See G. Cain, Married Women in the Labor Force, Table 33, p. 107.

${ }_{25}$ Another possibility is that because the wages assigned in the construction of the labor income variable do not differ by race, black labor incomes are too high and black wives appear to be working "too much." If black wages were overstated in the computation of labor income, the residuals would be systematically biased and correlated with race. But occupations were, for the 
Contemporary studies on black and white female labor force participation have found results similar to those reported here. Black women with the same economic and demographic characteristics as their white counterparts participate to a greater extent in the labor market. Glen Cain's study, using variables almost identical to those employed in this paper, found that black women between 35 to 39 years old, with 12 years of education, a child under six years old, and family labor income of $\$ 5,000$, had a probability of being in the labor force almost four times that for a white woman of identical characteristics. Many explanations have been offered for this and similar findings. Some have claimed that the life-cycle marital experiences of black and white women differ. Black women stand a greater chance of being unmarried with dependents and therefore do not exit from the labor force during their married years. They are, in some way, hedging against their having to support children sometime in the future. Discrimination in both the labor market and the housing market has also been suggested as a possible explanation. Black women may be faced with less discrimination in the labor market than their husbands, causing a substitution toward female labor in the family. Black housing might be of lesser quality than desired and its residents may therefore have less incentive to remain in the household. The higher incidence of the extended family structure and a closer community might also be responsible for the smaller response of black women to the presence of young children. All of these suggestions provide possible rationalizations for the recent findings, although none of these hypotheses seems to account fully for the large difference between black and white women observed in this sample.

\section{CONCLUSIONS}

This study has found that race is very important in explaining differences in labor force participation among females. Black women in this sample worked more (holding family labor income, wealth, the presence of children, and other characteristics constant). I have suggested that the slave experience might be partially responsible for this residual. Slavery seems to have left an indirect legacy on black and white women. It changed the relative valuations that black and white women had for work-possibly lowering that of whites and

most part, racially segregated and research by Robert Higgs indicates that wages by race were equal for given occupations in 1900. See R. Higgs, "Racial Wage Differentials and Segregation in Competitive Labor Markets: An Empirical Report," University of Washington, Discussion Paper No. 75-8 (Sept. 1975). 
raising that of blacks. Somewhat similar developments probably occurred among white women in the North because of the presence of immigrant women. Thus native-born females may have remained out of the labor force, despite their economic position, because woman's work became socially stigmatized. ${ }^{26}$

The role of social forces in determining the labor force participation of women in 1870 and 1880 was dramatized in the literature of the period. Orra Langhorne wrote in 1886 that there is "a very great need for occupations in which white women could support themselves . . . [T] he cigarette factories [in Virginia] were employing three hundred white girls . . . [however] married women were not accepted."27 Somewhat later Greene and Woodson wrote of the 1870s that “. . . Southern poor whites . . . looked upon domestic service as a "Negro job' [and therefore] Negroes encountered virtually no opposition" in entering this field. ${ }^{28}$ In my own research I have tried to model these statements so that they can be rigorously tested. The results indicate that economic and demographic differences alone cannot entirely explain black and white female labor force participation rates; to me it seems likely that these findings can be attributed to an indirect legacy of slavery.

Claudia Goldin, Princeton University

\footnotetext{
26 This proposition will be tested with the data from the Philadelphia Social History Project.

27 Quoted in Anne Firor Scott, The Southern Lady: From Pedestal to Politics, 1830-1930 (Chicago: University of Chicago Press, 1970), p. 122.

${ }^{28}$ Lorenzo J. Greene and Carter G. Woodson, The Negro Wage Earner (Washington: The Association for the Study of Negro Life and History, Inc., 1930), p. 31.
} 